\title{
ARSITEKTUR RUMAH ULU OGAN
}

\author{
Husnul Hidayat ${ }^{1, *}$ \\ ${ }^{1}$ Program Studi Teknik Arsitektur, Fakultas Teknik, Universitas Sriwijaya, Jalan Raya Palembang \\ Prabumulih Km.32 Indralaya Ogan Ilir, 30862 \\ *hhidayat71@gmail.com
}

\begin{abstract}
ABSTRAK. Rumah Ulu adalah rumah tradisional yang berada di daerah uluan Sumatera Selatan. Sebaran Rumah Ulu di daerah Pasemah, Semendo, Minanga, Lamban Tuha dan Ogan. Rumah Ulu adalah rumah panggung dengan bentuk dasar segi empat dan kemiringan atap yang curam. Rumah Ulu di daerah Ogan disebut Rumah Ulu Ogan dan bisa dijumpai di tepian sungai Ogan. Kondisinya kurang terawat dan sudah banyak mengalami perubahan bentuk maupun bahan konstruksinya. Penelitian ini bertujuan untuk mengkaji arsitektur Rumah Ulu Ogan. Lokasi penelitian berada di permukiman Desa Mendala, Kecamatan Peninjauan Ogan Komering Ulu. Hasil identifikasi selanjutnya dianalisis untuk menentukan karakter arsitekturnya. Hasil penelitian menunjukkan, Rumah Ulu Ogan memiliki tampilan yang khas yang tidak dimiliki pada Rumah Ulu daerah lainnya, yaitu tiang-tiang tinggi yang menopang atap pada teras depan. Denah rumah bangunan inti berbentuk segi empat dengan tambahan ruang pada sisi kanan, kiri dan belakang serta beranda rumah ada di sebelah kiri. Tidak ada sekat yang permanen dalam rumah. Atap pada bangunan inti berbentuk pelana dengan kemiringan 55 derajat yang terhubung dengan atap tambahan di sekelilingnya, bubungan atap datar atau tidak melengkung dan memiliki tebeng layar yang tegak. Ada ornamen ukiran pada bagian atap dinding dan balok lantai yang menghadap ke depan rumah. Tata letak Rumah Ulu Ogan berpola linier yang berlapis, memanjang dan sejajar aliran sungai juga orientasi bangunan tidak selalu menuju ke sungai.
\end{abstract}

Kata kunci: arsitektur, Rumah Ulu, Ogan

ABSTRACT. Rumah Ulu is a traditional house located in Uluan area of South Sumatra. The distribution of Rumah Ulu in the area of Pasemah, Semendo, Minanga, Lamban Tuha and Ogan. Rumah Ulu is a stilt house with a rectangular base shape and a steep roof slope. Rumah Ulu in the Ogan area is called Rumah Ulu Ogan and can be found on the banks of the Ogan river. The conditions are lack of maintenance and have undergone much change in shape and construction materials. This research is aimed to study the architecture of Ogan's house. The research site is located in the Mendala village settlement, Sub-District of Ogan Komering Ulu District. Further identification results are analyzed to determine the character of the architecture. The result shows Rumah Ulu Ogan has a distinctive look that is not owned in the home of other areas, namely high poles that support the roof on the front porch. House structure of the rectangular core building with additional space on the right side, left and back and the porch of the house on the left. There is no permanent bulkhead in the house. The roof of the saddle-shaped core building with a 55-degree slope connected to an additional roof around it, a flat roof ridge or non-curved and has an upright sidewall. There are ornaments carved on the roof of the walls and floor beams that face the front of the house. The layout of Ogan's house is linearly patterned, elongated and parallel to the flow of the river also the orientation of the building does not always go to the river.

Keywords: architecture, Rumah Ulu, Ogan

\section{PENDAHULUAN}

Rumah Ulu Ogan merupakan salah satu tipe rumah Ulu di Sumatera Selatan yang masih dapat dijumpai di sepanjang tepian sungai Ogan [2]. Tidak banyak lagi ditemukan rumah Ulu Ogan yang masih utuh. Kondisinya sudah banyak mengalami perubahan dari bentuk aslinya, seperti perubahan fungsi ruang bawah menjadi ruang hunian seperti kamar tidur dan warung. Selain itu, terjadi perubahan penggunaan material dari kayu menjadi beton sebagai pengganti bagian-bagian yang telah lapuk.

Sebagai produk arsitektur tradisional, belum banyak penelitian atau kajian yang membahas arsitektural rumah Ulu Ogan. Untuk itu, dalam rangka pelestarian dan perlindungan arsitektur tradisional diperlukan kajian terhadap rumah Ulu Ogan guna melihat karakteristik atau gaya arsitekturnya. Lokasi penelitian berada di permukiman desa Mendala, kecamatan Peninjauan, Ogan Komering Ulu, Sumatera Selatan. Pemilihan lokasi didasarkan atas 
masih banyaknya sebaran rumah Ulu Ogan yang berada dalam satu kawasan permukiman.

Produk arsitektur yang diwariskan nenek moyang terdahulu sudah teruji mampu beradapatasi dengan alam dan lingkungan serta memiliki nilai-nilai budaya yang tidak dapat dipisahkan. Untuk melihat arsitektural secara utuh, diperlukan identifikasi dari aspek bentuk atau rupa serta nilai-nilai filosofis atau pemaknaan dari obyek tersebut. Aspek bentuk dapat berupa tampilan seperti, atap, dinding, tiang/kolom, teras dan tangga sedangkan nilainilai filosofis dapat berupa orientasi, tata letak dan peruangan.

Tulisan bertujuan untuk mengidentifikasi arsitektur rumah Ulu Ogan sehingga dapat dijadikan sumber keilmuan dan arahan dalam mendisain untuk sekarang dan akan datang serta nilai filosofisnya sebagai bentuk upaya pelestarian arsitektur tradisional di Sumatera Selatan

\section{METODE PENELITIAN}

Metoda yang digunakan dalam penelitian ini adalah deskriptif kualitatif, dimana data-data dikumpulkan dengan cara observasi lapangan di kawasan permukiman desa Mendala dan studi literatur yang berhubungan dengan obyek penelitian. Hasil identifikasi terhadap tampilan bentuk fisik dari beberapa rumah Ulu Ogan di analisis guna mendapatkan arsitektur rumah Ulu Ogan yang mewakili dan selanjutnya dapat dikaji dari aspek tata letak dan orientasinya serta dari aspek pemaknaan atau nilai-nilai filosofisnya.

Pertimbangan pemilihan lokasi adalah masih banyak terdapat rumah Ulu pada permukiman desa Mendala, posisi rumah berderet atau bersebelahan dan berhadapan.

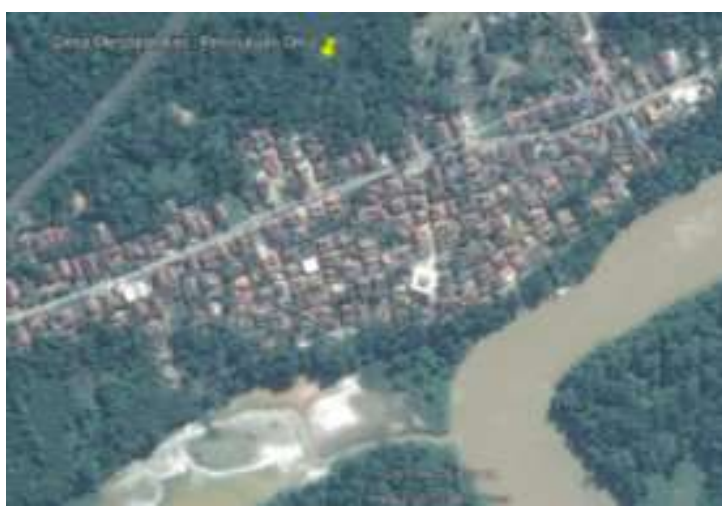

Gambar 1. Citra Satelit Desa Mendala, OKU (Sumber: Google earth, 2017)

\section{RUMAH ULU}

Dikatakan rumah Ulu karena letaknya yang berada didaerah Ulu atau pedesaan [3]. Sebaran rumah Ulu berada didaerah dataran tinggi Besemah, Semendo, Lamban Tuha dan dataran rendah Ogan [2]. Rumah Ulu dibeberapa daerah tersebut memiliki banyak persamaan dan perbedaan.

Struktur formal dari rumah Ulu yaitu bagian badan rumah berbentuk kotak yang bertumpu diatas tiang-tiang dan balok, posisi badan rumah menjorok keluar, tidak sejajar dengan tiang-tiang panggung layaknya seperti kantilever. Bagian tiang-tiang bangunan inti rumah Ulu berasal dari batang kayu berdiameter besar yang bertumpu diatas batu. Tiang-tiang tersebut dihubungkan oleh balok dan susunan balok lantai yang akan mendukung bangunan inti. Atap rumah Ulu berupa konstruksi kayu, berbentuk pelana dengan kemiringan yang cukup curam. Ruang atap yang cukup luas dimanfaatkan sebagai tempat penyimpanan barang $[1-2,4]$.

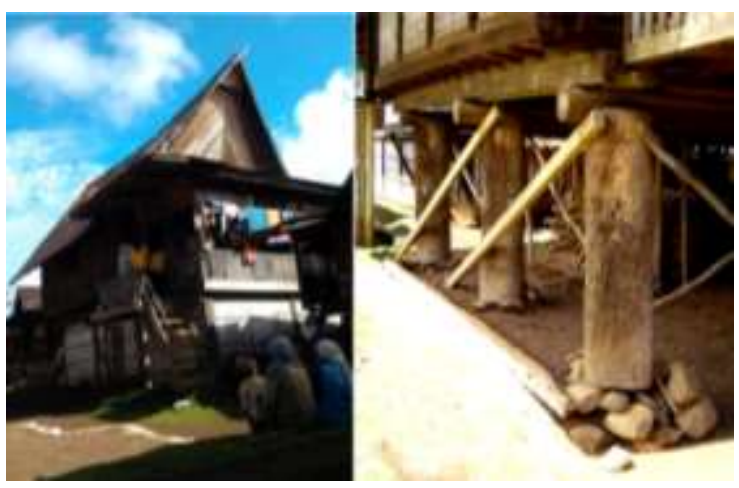

Gambar 2. Rumah Besemah

(Sumber: Dokumentasi Pribadi, 2016)

\section{HASIL DAN PEMBAHASAN}

\section{Rumah Ulu Ogan}

Rumah Ulu Ogan adalah rumah rakyat biasa asli setempat. Rumah berbentuk panggung dimana tiang-tiangnya bertumpu diatas umpak batu dan tidak ditanam seperti rumah Ulu pada umumnya. Bila dilihat lebih detail terdapat perbedaannya. 


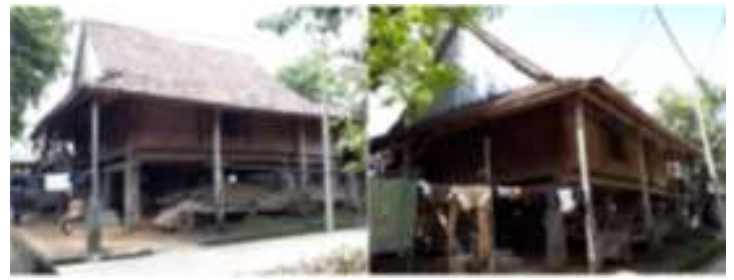

Gambar 3. Rumah Ulu Ogan

(Sumber: Dokumentasi Pribadi, 2017)

Ciri khas pada tampilan wujud yang tidak terdapat pada rumah Ulu daerah lainnya yaitu terdapat tiang-tiang tinggi yang menopang atap trtitisan pada bagian depan rumah. Jumlah tiang beragam ada yang empat, lima, tujuh, delapan tergantung penambahan ruang pada sekeliling bangunan inti.

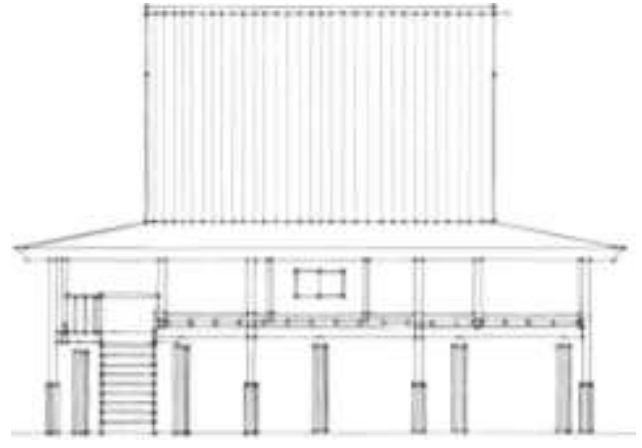

Gambar 4. Tampak Depan Rumah Ulu Ogan (Sumber: Hasil Identifikasi, 2017)

\section{Denah}

Denah bangunan inti berbentuk segi empat dengan ukuran yang beragam antara $5 \times 5 \mathrm{~m}$, $6 \times 6 \mathrm{~m}, 7 \times 7 \mathrm{~m}$. Terjadi penambahan ruang pada sisi kanan, kiri dan belakang dari bangunan inti.. Penambahan yang terjadi diperuntukkan untuk dapur pada bagian belakang dan kamar pada bagian samping kanan. Penambahan tersebut membuat timbulnya struktur baru berupa tambahan tiang-tiang panggung. Tidak ada pemisah sekat yang permanen didalam ruang. Dinding bangunan inti bagian belakang dilepas dan hanya menyisakan kolom. Beranda umumnya terletak disebelah kiri. Ada perbedaan tinggi lantai antara beranda dengan ruang dalam dan pada ruang dalam tidak ada perbedaan ketinggian lantai.

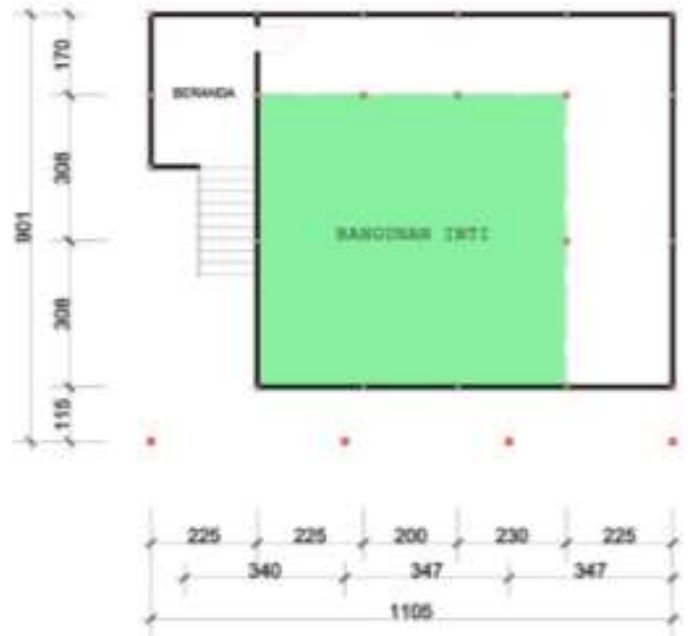

. Gambar 5. Denah Rumah Ulu Ogan 01 (Sumber: Hasil Identifikasi, 2017)

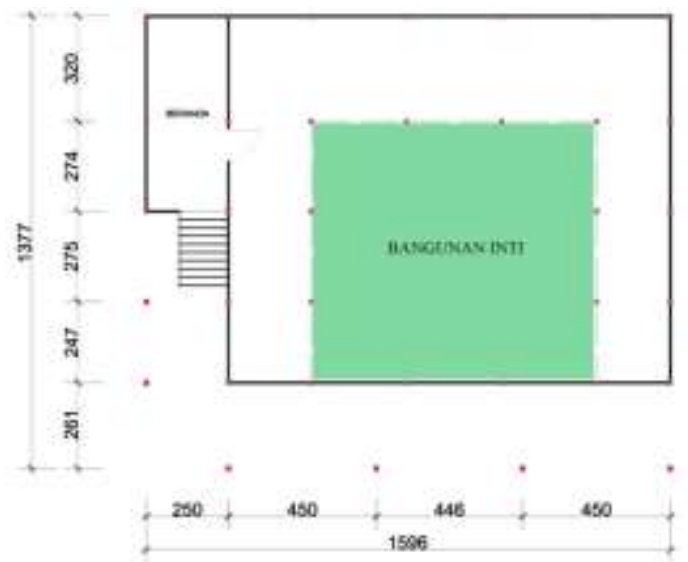

Gambar 6. Denah Rumah Ulu Ogan 02 (Sumber: Hasil Identifikasi, 2017)

Tidak adanya perbedaan elevasi lantai pada ruang dalam, menunjukkan rumah Ulu Ogan di desa Mendala adalah rumah rakyat biasa. Tidak ada tingkatan lantai seperti pada rumah Ulu pada daerah lain, yang dimaksudkan untuk menunjukkan kedudukan ruang atau tingkat status sosial pengguna.

\section{Tiang}

Rumah Ulu Ogan berbentuk rumah panggung. dengan maksud mengantisipasi musim pasang dan gangguan binatang buas. Tiang rumah bertumpu diatas batu dan tanah (tidak dibenamkan), hal tersebut akan berpengaruh pada fleksibilitas konstruksi bangunan saat terjadi gempa karena strukturnya tidak kaku.

Tiang rumah berasal dari kayu gelondongan berdiameter $50 \mathrm{~cm}-90 \mathrm{~cm}$. terdapat 9 tiang untuk bangunan inti. Ruang bawah rumah berfungsi sebagai tempat penyimpanan padi, 
kayu bakar, alat bertani, alat rumah tangga, kandang ayam dan lain-lain
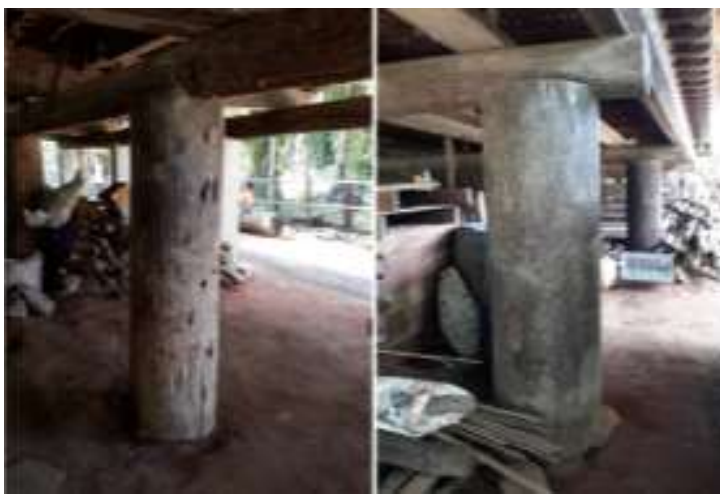

Gambar 7. Tiang Rumah Ulu Ogan (Sumber: Hasil Identifikasi, 2017)

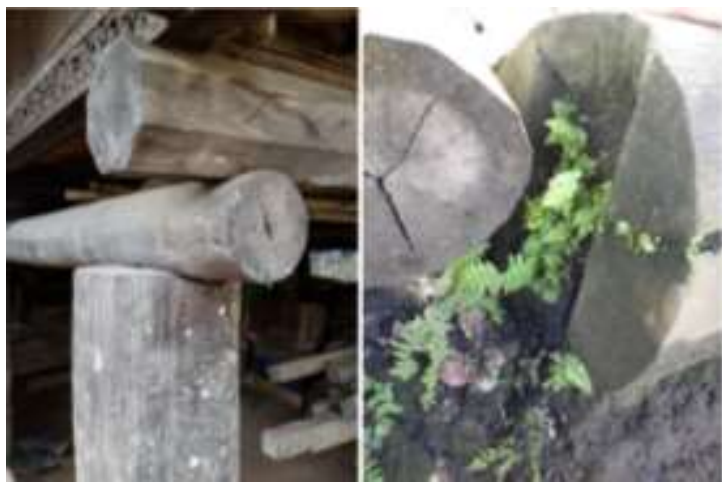

Gambar 8. Pertemuan Tiang dan Balok (Sumber: Hasil Identifikasi, 2017)

Terdapat coakan antara pertemuan tiang dan balok agar balok tidak bergerak serta ditemukan "ijuk (bahan sapu)" diantara himpitan balok dan tiang yang berfungsi sebagai anti rayap alami. Bagian balok lantai berbentuk segi delapan dan bila terjadi goyangan/gempa balok lantai akan bergerak/menggelinding "step by step" mengikuti segi delapan bentukan balok lantai.

Tidak ditemukan nilai-nilai filosofi dari tiangtiang panggung ini. Namun, dari beberapa ulasan diatas dapat kita simpulkan bahwa faktor ekologi, geografi wilayah menjadi dasar pertimbangan penggunaan konstruksi panggung dengan tiang yang bertumpu diatas batu dan tidak ditanam kedalam tanah dikarenakan berada di dataran rendah.

\section{Badan Rumah}

Bagian badan rumah inti berbentuk kotak dan berkantilever serta terdapat satu buah jendela menghadap muka. Badan rumah tidak terlalu tinggi, sekitar 2,25 m. Struktur dinding terekspos, dinding terbuat dari susunan papan. Memiliki satu jendela yang menghadap kedepan. Ornamen atau ukiran terdapat pada bagian kolom dinding dan rangka lantai. Namun, ada juga rumah Ulu Ogan yang tidak memiliki ukiran. Ukiran hanya terdapat pada sisi luar bangunan.

Makna filosofi yang terkandung pada tampilan badan rumah adalah nilai estetika berupa ornamen ukiran pada sisi yang menghadap jalan. Walaupun tidak banyak, namun ukiran yang ada memberikan nilai estetika. Belum ditemukan makna dibalik motif ukiran tersebut. Bukaan dinding yang menghadap kejalan memudahkan interaksi dari dalam keluar sedangkan minimnya bukaan jendela merupakan bentuk respon terhadap faktor ekologi.

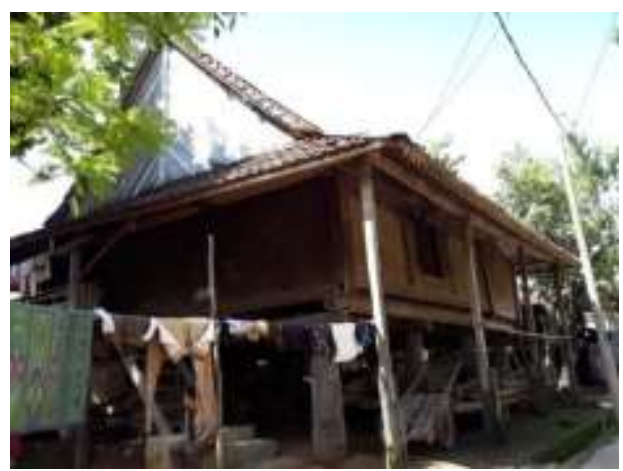

Gambar 9. Dinding Rumah Ulu Ogan (Sumber: Hasil Identifikasi, 2017)

\section{Atap}

Bentuk atap rumah Ulu Ogan merupakan atap pelana, dengan kemiringan sudut atap pada bangunan inti sekitar 55 derajat. Atap pada ruang tambahan lebih landai dan terhubung dengan atap inti. Penutup atap dari genteng kodok dengan kontruksi atap dari kayu, bubungan atap datar atau tidak melengkung dengan tebeng layar datar yang ditutupi oleh papan kayu. Konstruksi atap berupa kayu dengan kuda-kuda yang tidak umum. Tidak ada persilangan lisplang pada ujung atap.

Tidak ditemukan makna filosofi dari bentukan atap rumah Ulu Ogan. Namun, pertimbangan ekologi, seperti curah hujan menjadi faktor utama yang menyebabkan kemiringan atap yang curam serta memiliki tritisan yang cukup panjang kearah muka.

\section{Tata Letak}

Pola permukiman rumah Ulu Ogan di desa Mendala berbentuk linear dan terdiri dari beberapa lapisan yang memanjang dan sejajar aliran sungai. Karena susunannya berlapis maka orientasinya tidak selalu mengarah ke sungai dan tidak ada hirarki pada susunannya. 
Jarak antar rumah berdekatan baik bersebelahan maupun berhadapan dantidak berpagar. Hal tersebut menunjukkan adanya nilai sosial berupa hubungan interaksi yang erat antar rumah.

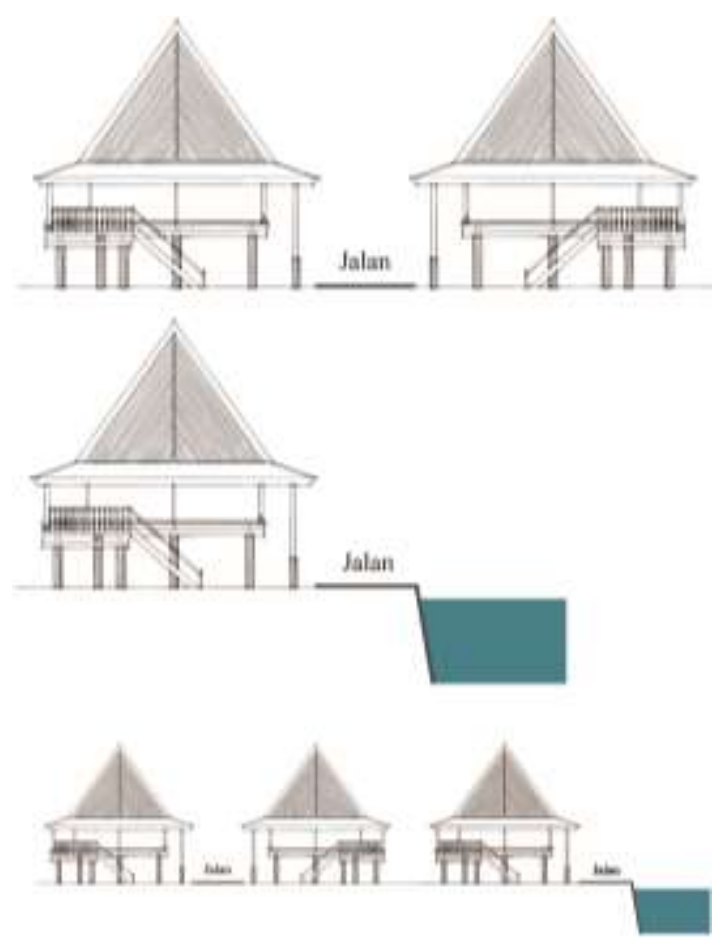

Gambar 10. Tata Letak

(Sumber: Hasil Identifikasi, 2017)

\section{KESIMPULAN}

Rumah Ulu Ogan adalah tipikal rumah rakyat biasa asli setempat. Dikatakan rumah asli dikarenakan terdapat sebuah rumah hasil dari tranformasi rumah Ulu dan rumah limas yang berasal dari ilir, rumah tersebut merupakan rumah bangsawan.

Karakter tampilan dari rumah Ulu Ogan adalah terdapat tiang-tiang tinggi pada bagian teras depan rumah untuk menopang atap tambahan berupa tritisan pada bagian depan. Tiang-tiang tersebut berada pada bagian muka dan jumlahnya bervariasi tergantung besaran rumah. Bangunan inti rumah Ulu Ogan berukuran relatif kecil, bervariasi $5 \times 5 \mathrm{~m}, 6 \times 6 \mathrm{~m}$, $7 \times 7 \mathrm{~m}$. Denah rumah berbentuk persegi dan mengalami perkembangan pada sisi kanan, kiri dan belakang dari bangunan inti. Teras dan tangga umumnya berada pada sebelah kiri.

Rumah Ulu Ogan berupa rumah panggung. Tiang-tiang rumah berdiri diatas umpak batu, tidak ditanam seperti halnya rumah Ulu yang berada di dataran tinggi Basemah dan Semendo. Dikarenakan geografis wilayah
Ogan yang termasuk dataran rendah, dekat aliran sungai dan terjadi pasang surut sungai.

Bagian badan rumah Ulu Ogan memiliki struktur dinding yang timbul keluar. Dinding rumah berupa pasangan papan kayu dan terdapat jendela yang menghadap ke muka atau jalan. Tidak terdapat perbedaan elevasi lantai pada ruang dalam, lain halnya dengan rumah Ulu di daerah lainnya.

Atap memiliki kemiringan yang curam hingga 55 derajat dengan tritisan yang sukup panjang dan ditopang oleh tiang-tiang tinggi pada bagian yang menghadap kejalan. Ciri yang paling membedakan rumah Ulu Ogan dengan rumah Ulu didaerah lainnya adalah adanya tiang-tiang tinggi yang menopang tritisan atap pada bagian muka dan itu tidak ditemukan pada daerah lain.

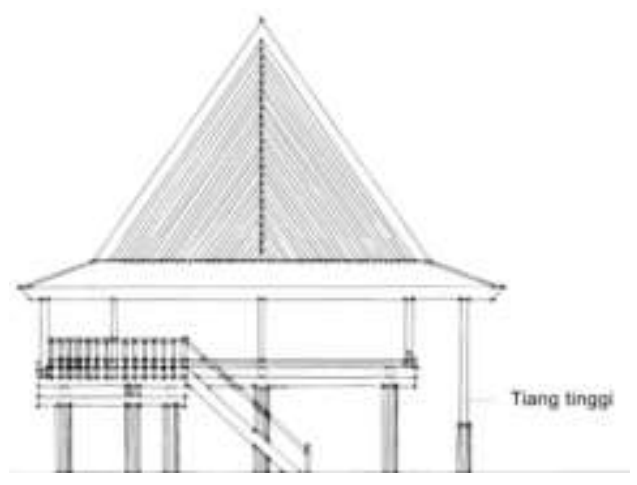

Gambar 11. Tampak Kiri Rumah Ulu Ogan

(Sumber: Hasil Identifikasi, 2017)

Makna dan nilai-nilai filosofis yang terkandung dalam Arsitektur Rumah Ulu Ogan lebih cenderung pada faktor ekologi. Dimana konstruksi dan bentukan rumah beradapatasi dengan bentukan geografis wilayah dan lingkungannya. Tata letak bangunan yang berada dekat sungai, namun tidak selalu mengarah ke sungai. Jarak antar rumah yang berdekatan tanpa sekat pagar membuat interaksi sosial pemukim lebih baik

Rumah Ulu Ogan merupakan produk warisan arsitektur tradisonal yang patut dilestarikan, bangunan ramah lingkungan, menggunakan material alam dan setempat, arsitektur tropis dengan atap yang panjang. Desain rumah Ulu Ogan dapat ditransformasikan dalam perancangan rumah tinggal masa kini sebagai bentuk pelestarian arsitektur tradisional. 


\section{DAFTAR PUSTAKA}

[1] Barendregt, Bart. (1998). Architecture on the Move. Processes of Migration and Mobility in the South Sumatran Highlands, Leiden University, The Netherlands

[2] Nugroho, S and Hidayat. (2016).Tipologi Arsitektur Rumah Ulu di Sumatera Selatan. : $145-50$

[3] Siswanto, Ari (2009). Kearifan lokal arsitektur tradisional Sumatera Selatan Bagi Pembangunan Lingkungan Binaan, Jurnal Local Wisdom, vol. 1 No. 1 hal. 37-45 November 2009

[4] Sukanti, dkk. (1994). Rumah Ulu Sumatera Selatan, Departemen Pendidikan dan Kebudayaan Direktorat Jenderal Kebudayaan Museum Negeri Propinsi Sumatera Selatan ,Balaputra Dewa", Palembang. 